\title{
The Motivation of Earnings Management Practices in Indonesia Companies: Board of Directors Perspective
}

\author{
Abshor Marantika $^{1}$, Budi Djatmiko ${ }^{2}$, Citrawati Jatiningrum ${ }^{3}$, Purwohandoko ${ }^{4}$ \\ ${ }^{1}$ Department of Management, STIE Bangkinang, Indonesia \\ ${ }^{2}$ Department of Management, STIE STEMBI, Bandung, Indonesia \\ ${ }^{3}$ Department of Information System, STMIK Pringsewu, Lampung, Indonesia \\ ${ }^{4}$ Department of Management, Faculty of Economic, Universitas Negeri Surabaya, Indonesia \\ Correspondent author e-mail: abshor399@gmail.com
}

\begin{abstract}
This study provides evidence about underlying motivation the director encouraged practice of earnings management. Directors of manufacturing companies in Indonesia was to be sample in this research whose companies are listed on the Indonesia Stock Exchange (IDX). This research explores fourth types of motivation where are bonus motivation, political motivation, debt covenant motivation, and taxation motivation. The research method carried out using quantitative methods by questionnaire. Sample study used board of directors in Indonesia Stock Exchange (IDX). Research method analyzed by multiple regression. The results of this study reveal that the four of motivations have effect on earnings management practices. The evidence also shows that the highest directors motivation for earning management is come from political cost motivation. Then, it followed by bonus motivation, taxation motivation and debt covenant motivation. The fact is an overview the regulation condition in Indonesia plays important role in being intervention of financial statements presented by the company, while bonus motivation is also significant for young directors in conducting earnings management practices on Indonesia companies.
\end{abstract}

Keywords:

Earnings Management, Bonus Motivation, Political Cost Motivation, Debt Covenant Motivation

Article Received: 18 October 2020, Revised: 3 November 2020, Accepted: 24 December 2020

\section{INTRODUCTION}

According the agency theory by principal Jensen \& Meckling (1979), some key terms and concepts are required towards understanding agency theory. These are: agent (managers) employed by a principal (shareholders) to carry out a task on their behalf while agency denotes the relationship between a principal (shareholders) and their agent (manager). Maximizing the company's stock market value is its main purpose. As an agent in the company the managers are accountable for accomplishing the company's objectives of maximizing shareholders' wealth. Jerzemowska (2006) asserted that the performance of managers in achieving the company objectives indicates how successful the management is in adapting to changing circumstances. Thus, the ability to properly react quickly to changes in the business environment is an indication of the quality of the company's management. Agency theory assumes that all parties act for they self- interest, information asymmetry between managers appears as agents and shareholders as when managers are more know the information and prospects of the company in the future compared to shareholders and other stakeholders. This condition brings out the information gap between managers and owners the company, ultimately management has an opportunity to maximize their interests in a way perform earnings management. Earnings management practice is related to agency theory. This theory explains form an agency relationship that is not only related between managers and shareholders but also the relationship between managers and bondholders. Agency problems occur when the principal do not have access to make decisions so that the principal does not find out whether the decisions the agent makes will be decisive sustainability of the company in the future for the sake of company interests (Sochib, 2016). 
Conflict of interest between agent and principal is possible in the company because the agent does not act according to the principal's interests, thus triggering agency cost. Such activities as managers have an incentive to improve their own welfare by using the facilities provided by shareholders by changing future costs to the present period or vice versa in financial statements (Almalita, 2017). Behavior Earnings Management (EM) is explained in agency theory, while the manager as an agent is obliged to provide information about the condition of the company to the owner, the information provided is in the form of disclosure of accounting information such as the company's financial statements. However, managers sometime not in accordance with accounting information that describes the actual state of the company (Santoso, 2016). Therefore, agency theory explains three assumptions of traits humans include the following: 1) The assumption of human nature that humans tend to be selfish (selfinterest), 2) Humans have limited thinking power so they never think for the future (bounded rationality), 3) Humans always avoid risk (risk averse).

Based on these three assumptions, it can be concluded that each individual has a selfish nature so that there is an increase conflict of interest between shareholders and management (Lestari \& Murtanto, 2017).

There are various motivations that underlie and encourage a manager to have an opportunistic attitude. This motivation will make the engineering pattern of profits carried out by company management based on positive accounting. Based on Positive Accounting Theory (PAT) there are three hypotheses that form the basis of the main motivation for managers to make profits, namely management bonuses, contractual debt and political costs. Therefore, for bonus motivation, it is explained that the manager wants a bonus in order to achieve certain company performance targets. This bonus will motivate managers to manage income according to its purpose and at a certain level. among others, what the manager does is perform revenue management through increasing profits to get compensation from the company.

Previous research on the effect of tax planning on earnings management has been widely researched by several previous researchers, some of which are Sumomba (2010), Wijaya and Martani (2011) and Istianingsih (2016). Sumomba (2010) examines influence tax planning on earnings management in order to find out the management response to changes in manufacturing companies, while Wijaya and Martani (2011) examined the practice of deep corporate earnings management responding to the reduction in tax rates according to Law no. 36 of 2008. Results of studies the previous varied so that it provides an opportunity for further research, either which are repetitive (replicative) and developmental. This study attempts to provide evidence related to the motivation that drives or the board of directors to perform earnings management. Several factors (bonus motivation, political cost motivation, debt covenant, and taxation motivation) are tested to determine which factors that are strong drivers of earnings management, especially in companies listed on the Indonesia Stock Exchange. Evidence would be documented the motivation generally carried out by managers in conducting earnings management.

\section{LITERATURE REVIEW}

\section{a. Agency Conflict}

Agency theory described by Jensen and Meckling (1976) explains that the principals are the owners of the company and the agent is the manager. Agency cost appears if returned to the residual claimant, the owner, lower than the principals as the owner directly to control the corporation (Jatiningrum et al, 2016; Djazuli, et al, 2020). Eisenhardt (1989) also stated that agency theory is the mechanisms that specifically to reduce the agency cost, an incentive scheme for managers in the form of reward financially to maximize the benefit of the shareholders The schemes in term of includes plans whereby shares to be acquired senior executive, perhaps with a reduced share 
price. Therefore, for aligning financial interests of executives with those of other shareholders (Jensen \& Meckling, 1976). However, agency relationship dominates most business organisations. Many company directors have managed companies where are not as owner. Therefore, agency problems in the company have arisen due to the separation ownership and control. Agency issues arise in the company based on the power distribution within the control of organization between shareholders as the owners and control. Jansen and Meckling (1976) conclude this is due to the different interests and goals of the stakeholders of the company. Given the distributed ownership and realization of management that capital requirements can be obtained from owners, shareholders and lending from debtholders, thus agency problem becomes wider. It should be point out that the most critical conflict of interests in the company arise between shareholder and managers. Indeed, there was lead potential conflicts of interests while the separation between ownership (shareholders) and control (directors). Based on discussion above, thus corporate governance has been developed due to the many problems which have arisen in the past. While under the agency theory, manager or agent is presumed to act rationally and maximize the interests of the moral hazard and adverse selection which has crucial consequences in financial accounting. According to Scott (2003), moral hazard promotes the interests of board as managers in the choice of accounting policies. Therefore, the choice of accounting policies can influence the quality of profit or earnings information. This is because users of financial statements view earnings reporting as a main report and has remained a primary issue in accounting research (Subramayam, 1996; Dechow, 1994; DeFond \& Park, 2001).

\section{b. Earnings Management}

There is a lack of consensus on the definition of earnings management and what if implies due to varying interpretations of empirical evidence in studies that seek to detect earnings management, or to provide evidence of earnings management incentives. The earnings management literature endeavours to comprehend why managers manipulate earnings, how they do so and the outcomes of this behaviour. There is broad interest in literature reviews by Schipper (1989), Dechow and Skinner (2000) and Healy and Wahlen (1999). These are the popular attempts at defining earnings management. Schipper (1989) describes earnings management as follows: "A purposeful intervention in the external financial reporting process, with the intention of obtaining some private gain... [a] minor extension of this definition would encompass "real" earnings management, accomplished by timing investment or financing decision to alter reported earnings or some subset of it.". Healy and Wahlen (1999) stated that earnings management ".... occurs when managers use judgment in financial reporting and in structuring transactions to alter financial reports to either mislead some stakeholders about the underlying economic performance of the company or to influence contractual outcomes that depend on reported accounting numbers." Earnings management behaviour can be described through Positive Accounting Theory (PAT) and the Agency Theory. Three hypotheses that PAT can be used as a basis for understanding the actions of earnings management was promoted by Watts \& Zimmerman (1986) and was reaffirmed by Scott (2003). Scott (1997; 2003) summarized the major incentives for earnings management, such as Bonus motivation, Political Cost, Debt Covenant, and taxation motivation.

In the financial accounting, the elements of accounting method which used in company and policy of managers regarding the practice of discretion through accounting estimations that would affect in net income. A key element of any assessment for earnings management is the degree of management's discretion over earnings. Mc Nicholas (2000) classify several approaches based on the literature. There is an extensive literature that tries to recognize discretionary accruals based on the relationship between total accruals and hypothesized explanatory factors. 


\section{c. Bonus Motivation}

According to the first hypothesis in PAT theory, known as is the "bonus plan hypothesis". This hypothesis states that the manager of the company on bonus plan is likely to use accounting methods that would increase the current income. In other words, for companies which have bonuses plans, managers will be in favour of accounting method that move profits from the future into the present, so as to inflate current earnings. This is because the manager prefers giving higher wages to the present. In the bonus contracts this is known as two-term bogey (lowest profit level to get the bonus) and a cap (the highest income level). If the earnings are under a bogey, then no bonus is earned by manager whereas if income is above the cap, the manager will not get additional bonuses. If net income is under bogey, managers incline to lessen profits in the hope of bigger bonuses in the next period, as well as if income is above the cap. Therefore, only if the net income is between the bogey and cap, managers will attempt to raise the company's net profit. (Jatiningrum et al., 2016). In the bonus plan or managerial compensation, the owner of the company promised that the manager will receive a bonus if the performance of the company reaches a certain amount. This means that the bigger the bonus that When the bonus of managers is based on reported earnings, they will have incentives to manage these earnings to increase the expected value of their bonus. In study Djazuli et al. (2020) documented report of Healy (1985) study which earnings management behaviour is affected by the terms of managers' bonus plans and whether these plans include any upper or lower limits of earnings from which bonus is taken. More specifically, managers are more likely to increase reported earnings when these earnings are between the lower and upper limits. However, managers are more likely to use income-decreasing accrual or engage in a "big bath" activity when earnings are above the upper limit or below the lower limit to "save" these earnings for next periods and increase their expected bonus in the future (Scott, 2003). Based on this discussion, this following proposes hypothesis:

H1: Board of Directors are motivated to carry out the earnings management due to bonus motivation (moral hazard)

\section{d. Political Cost Motivation}

Large firms are usually more politically visible because their activities affect a large number of people. Also, firms in strategic industries and monopolistic or near monopolistic firms are also more publicly visible. Such firms may tend to decrease their reported earnings to reduce their political cost (Nurdiniah \& Herlina, 2015). Political costs involve all anticipated costs imposed on a firm from potential adverse political actions including antitrust, regulation, government subsidies, taxes, etc. Firm size is a scale in which large and small companies can be classified. Watts, Zimmerman (1986) in the PAT stated that the company size are used as guidelines for the political costs. Political costs preferred done with companies in earnings increasing based on the firm size and risk. It also would be negative effect of firm size with earnings management. Evidences also reported studies by Cahan (1992) Han \& Wang (1998) Key (1997) documented that companies were more likely to be affected by the outcome of regulations for used more incomedecreasing accruals. Based on the discussion above, the hypothesis proposed:

\section{H2: Board of Directors are motivated to carry out the earnings management due to political cost motivation}

\section{e. Debt Covenant Motivation}

According to" the debt covenant" hypothesis which states that for a company that has a large debt to equity ratio, the company's managers tend to use accounting methods that will increase revenue and profit. Based on the hypothesis of a debt contract, the company will conduct an aggressive earnings management to prevent violations of the debt contract (Watts, 
Zimmerman, 1986). Aryani (2011) Nurdinah \& Herlina (2015) documented in Indonesia companies which have a high leverage ratio tend to carry out earnings management. Earnings management preferred to be made because the company will experience difficulties in obtaining additional funding from creditors and can even threaten the company if it is unable to meet its payment obligations on time. thus the company is encouraged to increase profit (accrual revenue increases) to avoid violating the debt limit. The greater the leverage the company has, the greater the manager's motivation to manage earnings. Therefore, the amount of debt the company will motivate management to manage earnings. managers will prefer method of accounting to suspend reported earnings of the current period to another period so as to minimize future reported earnings. The political costs appear high due to the profitability of companies that can attract the attention of the media and consumers. Thus, this following hypothesis is stated:

\section{H3: Board of directors are motivated to carry out the earnings management due to debt covenant motivation}

\section{f. Taxation Motivation}

Taxes are an important source of state revenue for financing state development. One of the largest tax sectors for the state is income tax. The taxation authorities tend to impose their own accounting rules for calculation of taxable income, therefore firms may have less incentive to manage earnings for tax purposes. In Indonesia, the tax calculation policy provides incentives for companies to carry out earnings management by reducing taxable income, so that the company's tax burden will be smaller (Wijaya \& Martani, 2011; Aditama \& Purwaningsih, 2014).

H4: Board of directors are motivated to carry out the earnings management due to taxation motivation
It would sum up discussion above several factors that affecting the motivation board of directors in managing earnings can be shown on this figure:

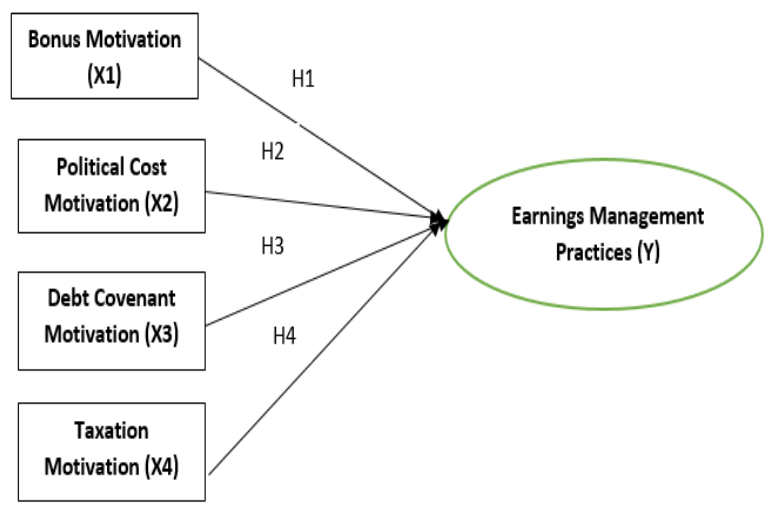

Figure 2 Research Framework

\section{RESEARCH METHOD}

This study is explanatory in type. Explanatory research is a type of research that explains the causal relationship between variables through hypothesis testing (Singarimbun \& Effendi, 2006). Analysis data in this study uses quantitative approach to assess the effect of independent variables (earnings management) motivation and dependent variable (earnings management). This study gives a new evidence that investigated the motivation of managerial in the companies arrange the earnings management.

This study uses quantitative data in the form of numerical data from respondents' answers from questionnaires using SPSS version 23. This study uses a Likert scale with data obtained from the four independent variables (23 items) and the dependent variable (4 items). Besides that, the data were also obtained using interviews with company directors or managerials as supporting data. Supporting document research is carried out to strengthen research arguments.

Sample selection with purposive sampling method. Respondent in this study are directors of companies listed on the Indonesia Stock Exchange. The number of samples obtained from distributing questionnaires for selected respondent. Selection by purposive sampling 
method used to ensure that the sample is a respondent who appropriate directors in case of earning management practices. After sample study run based on several criteria required, collected respondents in this study 85 member of board of directors which consisting of CEO, executive director and independent director. Therefore, because of this research is quantitative data in the form of processed data numbers from the answers to questionnaires. a validity and reliability test was conducted before analysis data. Technical analysis method using Multiple linear regression analysis is used when the independent variables are more than one. Analysis of determination is simultaneously used to determine the degree of dependency together (simultaneously) between the independent variables and the dependent variables.

\section{RESULT AND FINDING}

a. Findings

Table 1 The Demograpichs Caracteristics of the Respondents

\begin{tabular}{|c|c|c|c|c|c|}
\hline \multicolumn{2}{|c|}{ Information } & \multirow{2}{*}{$\begin{array}{c}\text { Frequency } \\
56\end{array}$} & \multirow[t]{2}{*}{ Total } & \multicolumn{2}{|c|}{ Percent } \\
\hline \multirow[t]{2}{*}{ Gender } & Male & & & 65.8 & \\
\hline & Female & 29 & 85 & 34.2 & 100 \\
\hline \multirow[t]{5}{*}{ Age } & Under 30 years & 2 & & 2.30 & \\
\hline & 30-39 years & 25 & & 29.40 & \\
\hline & $40-49$ years & 44 & & 51.70 & 100 \\
\hline & $50-59$ years & 13 & 85 & 15.29 & \\
\hline & 60 years and above & 1 & & 1.21 & \\
\hline \multirow[t]{8}{*}{ Experience } & 10 years or below & 13 & & & \\
\hline & $11-15$ years & & & 15.29 & \\
\hline & $16-20$ years & 29 & 85 & & 100 \\
\hline & More than 21 years & & & 34.11 & \\
\hline & & 31 & & & \\
\hline & & & & 36.40 & \\
\hline & & 12 & & 14.10 & \\
\hline & & & 85 & & \\
\hline Education & Bachelor degree & 32 & & 37.64 & \\
\hline \multirow[t]{3}{*}{ Background } & Master degree & 51 & & 60.00 & \\
\hline & Others & 2 & & 2.36 & 100 \\
\hline & & & 85 & & \\
\hline Position in & CEO & 23 & & 27.10 & \\
\hline \multirow[t]{3}{*}{ Company } & Executives Director & 46 & & 54.10 & 100 \\
\hline & Independent & 16 & & 18.80 & \\
\hline & Director & & & & \\
\hline
\end{tabular}

The table above presents the demographics of the respondents in this study. Respondents of this study were obtained as many as 85 respondents. Respondent information shows the demographics of male respondents $(65.8 \%)$ are higher than female respondents $(34.2 \%)$. While the majority of respondents were dominated by managerial or directors for more than 40 years old $(51.7 \%)$, this 
means that the directors already have experience in managing the company and most of them already have a fairly large productive period. Based on the table majority the directors have experiences 16-20 years (36.4\%). However, Directors in the companies as respondent have a position in executive directors $(54.10 \%)$.
Table 2 presents the validity test of each instruments. The value shows in the Corrected Item-Total Correlation column mostly more than 0.6. These result shows all the instruments declared valid.

Table 2 Validity Test of Variables

\begin{tabular}{|c|c|c|}
\hline & $\begin{array}{l}\text { Corrected } \\
\text { Items-Total } \\
\text { Correlation }\end{array}$ & Information \\
\hline $\mathrm{X} 1.01$ & 0.733 & Valid \\
\hline X1.02 & 0.682 & Valid \\
\hline X1.03 & 0.741 & Valid \\
\hline X1.04 & 0.761 & Valid \\
\hline X1.05 & 0.752 & Valid \\
\hline $\mathrm{X} 2.01$ & 0.695 & Valid \\
\hline $\mathrm{X} 2.02$ & 0.655 & Valid \\
\hline $\mathrm{X} 2.03$ & 0.701 & Valid \\
\hline X2.04 & 0.770 & Valid \\
\hline $\mathrm{X} 2.05$ & 0.698 & Valid \\
\hline X2.06 & 0.712 & Valid \\
\hline $\mathrm{X} 2.07$ & 0.722 & Valid \\
\hline X3.01 & 0.655 & Valid \\
\hline X3.02 & 0.683 & Valid \\
\hline X3.03 & 0.732 & Valid \\
\hline X3.04 & 0.761 & Valid \\
\hline X3.05 & 0.719 & Valid \\
\hline $\mathrm{X} 4.01$ & 0.773 & Valid \\
\hline X4.02 & 0.764 & Valid \\
\hline X4.03 & 0.744 & Valid \\
\hline X4.04 & 0.732 & Valid \\
\hline X4.05 & 0.711 & Valid \\
\hline X4.06 & 0.759 & Valid \\
\hline Y.01 & 0.761 & Valid \\
\hline Y.02 & 0.787 & Valid \\
\hline Y.03 & 0.722 & Valid \\
\hline Y.04 & 0.767 & Valid \\
\hline
\end{tabular}

The presentation of the Table 3 shows that the results of the reliability test on four independent variables and one dependent variable state that the Cronbach Alpha value is greater than 0.6 , meaning that it is declared reliable and can be tested further. Test of reliability by Cronbach Alpha statistical test, in the result shows that a construct or variable said to be reliable if it gives a Cronbach Alpha value > 0.60 (Ghozali, 2016). 
Table 3 Reliability Test

\begin{tabular}{|c|c|c|}
\hline Variables & $\begin{array}{c}\text { Cronbach's } \\
\text { Alpha }\end{array}$ & N of Items \\
\hline $\mathrm{X} 1$ & 0.922 & 5 \\
\hline $\mathrm{X} 2$ & 0.878 & 7 \\
\hline $\mathrm{X} 3$ & 0.829 & 5 \\
\hline $\mathrm{X} 4$ & 0.911 & 6 \\
\hline $\mathrm{Y}$ & 0.842 & 4 \\
\hline
\end{tabular}

Table 4 Kolmogorov-Smirnov Test

\begin{tabular}{llc}
\hline & & $\begin{array}{c}\text { Unstandardized } \\
\text { Residual }\end{array}$ \\
\hline $\mathrm{N}$ & Mean & 85 \\
Normal Parameters $^{\mathrm{a}}$ & Std. Deviation & 0.0000 \\
Most Extreme Differences & Absolute & 0.5123 \\
& Positive & 0.025 \\
Kolmogorov-Smirnov Z & Negative & 0.025 \\
Asymp. Sig. (2-tailed) & & -0.022 \\
\hline
\end{tabular}

a. Test distribution is Normal.

Table 4 present the Kolmogorov-Smirnov Test. This test aims to examine whether distribution residual is normal. Based on the results in Table 3, value of Asym Significance (2tailed) is 0.421 or $p$ value $=0.421>0.05$ indicates acceptance of Ho. This result of Kolmogorov
Smirnov-Test mean that the residual is normally distributed. This results also consistent with histogram graph, P-P plots. It means that regression model meets the assumption of normality. All the result of normality tests show that these data can be used for further testing.

Table 5 The Coefficient $\left(\mathrm{R}^{2}\right)$ Relationship between Motivation and Earnings management Model Summary

\begin{tabular}{ccccc}
\hline Model & $\mathrm{R}$ & -R Square & $\begin{array}{c}\text { Adjusted R } \\
\text { Square }\end{array}$ & Std. Error of the Estimate \\
\hline & & & & \\
1 & $0.715^{\mathrm{a}}$ & 0.672 & 0.654 & 0.37959 \\
\hline
\end{tabular}

a. Predictors: (Constant): $B N, P C, D C, T X$

b. Dependent Variable: EM

Aaccording to Table 5, the adjusted $R$ Square of $0.654(65.4 \%)$ indicates the level of variation in earnings management accounted for by independent variables of motivation of earnings management. The adjusted R-square signifies that $65.4 \%$ of changes in value of earnings managements is as a result of combined effects of the corporate governance mechanism 
(board of director size, board of commissioner size, independence of commissioners, institutional ownership, ownership concentration, audit committee, and independence of audit committee) while the remaining $34.6 \%$ were caused by other variables outside the model.

Table 6 Hypotheses Testing: Result of Direct and Indirect Relationships

\begin{tabular}{|c|c|c|c|c|c|}
\hline H & Structure Relationships & $\boldsymbol{\beta}$ & t-stat & $\boldsymbol{P}$-Value & Information \\
\hline H1 & BN $\rightarrow$ EM & 0.105 & 3.447 & $\mathbf{0 . 0 0 0} * * *$ & Accepted \\
\hline H2 & PC $\rightarrow$ EM & 0.131 & 3.325 & $\mathbf{0 . 0 0 0} * * *$ & Accepted \\
\hline H3 & DC $\rightarrow$ EM & 0.182 & 2.185 & $\mathbf{0 . 0 0 2} * * *$ & Accepted \\
\hline H4 & TX_ $\rightarrow$ EM & 0.171 & 3.021 & $\mathbf{0 . 0 0 0} * * *$ & Accepted \\
\hline
\end{tabular}

Based on Table 6 shows that the result of hypotheses test for examine the relationship for independent variables to the earnings management. The findings suggest that significantly affect between several motivations on earnings management practices.

According to the first hypothesis (H1), which proposed that Bonus motivation affecting the earnings management on Indonesia listed companies. Hypothesis 1 stated that board of Directors are motivated to carry out the earnings management due to bonus motivation (moral hazard) on Listed Companies in Indonesia. Statistics test presents the significance with the pvalue of $0.000 * * *(\beta=0.105$, $t$-stat $=3.447)$. It means that hypothesis is supported. This finding reveals that bonus motivation become one of motivation manager to conduct earnings management practices. The finding is consistent with Healy (1985), Jatiningrum e.t al. (2016), Djazuli et al. (2020).

Political Cost hypothesis (H2), suggestion that board of directors are motivated to carry out the earnings management due to debt covenant motivation. Table 6 presents that political cost as motivation manger tend to conduct earnings management with $p$-value $0.000^{* * *}(\beta=0.131 \mathrm{t}$ stat $=3.325)$. This result prove that political cost motivation tend to manager conduct earnings management practices. These findings reveal that the hypoteses (H2) was supported. This finding consistent with Cahan, 1992; Han \& Wang, 1998; Key, 1997; Nurdiniah \& Herlina (2015).
The third Hypothesis (H3) proposed that the board of directors is motivated to carry out the earnings management due to debt covenant motivation. According to the Table 6 presents that the relationship with p-value $0.002 * * *(\beta=0.182$ t-stat $=2.185)$. This result means that the debt covenant is the causes of managers doing earnings management. Evidence shows that companies listed in Indonesia mostly have a high level of leverage. Thus, the manager preferred to manage earnings, this is done for obtaining funding from creditors. The result also lines with result studies from previous evidence by Aryani (2011) Nurdinah \& Herlina (2015). Then for the last hypothesis (H4) stated that board of directors are motivated to carry out the earnings management due to taxation motivation has supported. Based on Table 6 shows that the relationship with pvalue $0.000^{* * *}(\beta=0.171 \mathrm{t}$-stat $=2.185)$. This finding means that motivate to manage earnings for tax purposes mostly done at Indonesia companies listed. This result accordance with PAT theory declared by Watts \& Zimmerman (1986) and previous studies by Wijaya \& Martani (2011) also with Aditama \& Purwaningsih, 2014).

\section{Discussion}

Empirical evidence from previous studies was documented that earnings management is considered a management intervention against financial reports. Management is permitted by the Accounting Standards to make accounting policy choices in the external financial reporting process. 
Several things are done with the aim of achieving personal goals, thereby reducing the credibility of the financial statements (Schipper, 1989). Earnings management can also be considered as actions that are not permitted if earnings management practices will impact the misleading and deceptive financial statement information of shareholders (Healy \& Wahlen, 1999), or as actions carried out by management as moral hazard (Beneish, 2001; Demski \& Sappingtont, 1987). There are several reasons why it is accompanied managers perform earnings management. Supporting by Priyastiwi et al. (2020) conducted experiment study on the role of managers' ethical orientation based on prosocial theory. The study investigates that mitigating the willingness of manger to conduct earning management practices which caused by asymmetry information. Using the role of ethical orientation to examine the relationship between asymmetry information, management status, and earnings management. The findings suggest that managers with high asymmetry information would prefer to do earnings management while it compared with managers with low asymmetry information.

The hypothesis test shows that board of directors strongly motivated to conduct earnings management. Based on the findings the result of hypotheses in this study, briefly the motivations affecting the pattern of managerial action in financial statement and management decision. Positive accounting theory (PAT) has three hypotheses which as form the basis of the main motivations that managers perform earnings. management bonuses, political costs, debt covenant and taxation. In the bonus motivation stated that manager have encouragement to get a bonus within performance targets. Johnson (2003) provides evidence that companies often take action in financial reporting interventions by their managers for the interests of these managers, not for the interests of their shareholders. Given the preparation and disclosure processes make it possible so that managers often act on their own (moral hazard) by manipulating company operations or by manipulating reported results. Anderson and Lauderback (1975) build on previous studies and find that manager would intervention on financial statement and 'follow GAAP' in a manner consistent with pattern maximize revenue or they are trying to conduct income smoothing. Some of the earnings management actions by income increasing and decreasing profits. Political cost and debt covenant result proved that in this case, the manager in listed companies in Indonesia perform earnings management by increasing profits in order to obtain greater compensation from the company. Manager tend to increase income by increasing accruals with intent to avoid breaching the debt limit. However, in Indonesia companies with greater the level of leverage on the company also greater with the motivation of managers to manage earnings. Last evidence related with taxation motivation presented that majority the large listed companies in Indonesia tend to make up accounting procedures by decreasing incomes for tax purposes. These finding accordance with the previous studies that the tax calculation policy provides incentives for companies to carry out earnings management by reducing taxable income, so that the company's tax burden will be smaller (Wijaya \& Martani, 2011; Aditama \& Purwaningsih, 2014), while bonus motivation is also significant for young directors in conducting earnings management practices on Indonesia companies.

Considering the board of director number in Indonesia, based on the recommendation above, evaluation of board performance and a promotion board diversity, are the ways of ensuring effective board performance. This will support the ability of the board of directors to manage and control the company. Furthermore, characteristics of the board such as composition of its membership affect board performance of its oversight function. The effectiveness of the oversight function of the board could be reflected in the composition, whether the appointment of board members come 
from within the company and / or from outside the company. Thus, Widyati (2013) argues that among Indonesia companies, the board of directors could not guarantee effective functioning and monitoring on performance management. An effective implementation of corporate governance is believed may minimize opportunistic behavior of the management and consequently improve firm performance (Sianturia et al., 2020).

\section{CONCLUSION}

The purpose of this study provides evidence related the motivation encouragement the board of directors manage the earnings. Several motivation factors examined directly effect to earnings management practices. The sample selection with 85 respondents from directors or manager in Indonesia listed companies analyzed with regressions statistics method. The findings reveal that bonus motivation, political motivation, debt covenant motivation, and taxation motivation are significant effect the earnings management practices. However, political cost motivation is the most of companies do. Therefore, the main findings are motivation directors or manager conduct earnings management due to market places interest. The limitation of this study was limited sample which conducted by manager in companies listed on the Indonesian stock exchange. Thus, the results not be generalized. Further research can take a sample of directors or managers from companies not listed in the capital market to obtain evidence of their motivation to carry out earnings management with different interests. The contribution of this discovery will be an input for the regulator in determining the policies that will be contained in the regulations in financial reporting

\section{REFERENCES}

[1] Jensen, M ., \& Meckling, W. (1976). Theory of the firm: managerial behavior, agency, and ownership structure. Journal of Financial Economic, 3, 305-360.
[2] Jerzemowska, M. (2006). The Main Agency Problems and Their Consequences. Acta Oeconomica Pragensia, 14(3), 9-16. https://doi.org/10.18267/j.aop.73

[3] Sochib (2016). Good corporate governance manajemen laba dan kinerja keuangan. Edisi.1, Cetakan. Yogyakarta: Deepublish

[4] Almalita, Y. (2017). Pengaruh corporate governance dan faktor lainnya terhadap manajemen laba. Jurnal Bisnis dan Akuntansi, 19 (2), 183-194. https://doi.org/10.23969/jrbm.v11i2.1256

[5] Susanto, Y. K. \& Pradipta, A. (2016). Corporate governance and real earnings management. International Journal of Business, Economics and Law, 9 (1), 1723

[6] Lestari, E., \& Murtanto (2017). Pengaruh efektivitas dewan komisaris dan komite audit, struktur kepemilikan, kualitas audit terhadap manajemen laba. Jurnal Media Riset Akuntansi, Auditing \& Informasi, 17 (2),

97-115.

Http://Dx.Doi.Org/10.25105/Mraai.V17i2. $\underline{2063}$

[7] Sumomba, Christina Ranty. (2010). Pengaruh Beban Pajak Tangguhan dan Perencanaan Pajak terhadap Praktik Manajemen Laba pada Perusahaan Manufaktur yang Terdaftar di Bursa Efek Indonesia. Skripsi Program Sarjana Universitas Atma Jaya Yogyakarta.

[8] Wijaya, Maxson dan Martani, Dwi. (2011). Praktik Manajemen Laba Perusahaan Dalam Menanggapi Penurunan Tarif Pajak Sesuai UU No. 36 Tahun 2008. Simposium Nasional Akuntansi XIV Aceh 2011. 
[9] Istianingsih (2016). Deteksi manajemen laba melalui discretionary revenue dan aktifitas riil: implikasi penerapan good corporate governance. Jurnal Riset Akuntansi Dan Keuangan. 4(3). https://Doi.Org/10.17509/Jrak.V4i3.466 $\underline{6}$

[10] Jatiningrum, C., Abdul-Hamid, M. A., \& Popoola, O. M. J. (2016). The impact of disclosure quality on corporate governance and earnings management: evidence from companies in indonesia. International Journal of Economics and Financial Issues, 6, 118-125.

[11] Djazuli, A., Jatiningrum, C., Fauzi, Mujiyati, (2020). The implementation of corporate governance and enterprise risk management: evidence in concentrated ownership context. Palarch's Journal of Archaeology of Egypt/Egyptology, 17 (6), 7169-7184.

[12] Healy, P. M. (1985). The Effect Of Bonus Shcemes On Accounting Decison. Journal Of Accounting And Economis, 7, 85-101.

[13] Eisenhardt, K. M. (1989). Agency Theory: An Assessment And Review. Academy Of Management Review, 14(1), 57-74.

[14] Subramanyam, K. R. (1996). The Pricing Of Discretionary Accruals. Journal of Accounting And Economics, 22, 249-281

[15] Dechow, P., M. (1994). Accounting Earnings And Cash Flows As Measures Of Firm Performance The Role Of Accounting Accruals. Journal Of Accounting And Economics, 18. 3-42

[16] Defond, M. L., \& Park, C. W. (2001) The Reversal Of Abnormal Accruals And The Market Valuation Of Earnings Surprises. The Accounting Review, July,76(3), 375404.

[17] Schipper, K. (1989). Commentary On Earnings Management. Accounting Horizon (December), 91-102.

[18] Dechow, P. M., \& Skinner, D. J. (2000). Earnings Management: Reconciling The Views Of Accounting, Academics,
Practitioners, And Regulators. Accounting Horizons, 14(2), 235-250.

[19] Healy, P. M \& Wahlen, J. M. (1999). A Review Of The Earnings Management Literature And Its Implications For Standar Setting. Accounting Horizon, 13 (December), 365-383.

[20] Scott, W. R. (2003). Financial Accounting Theory. Third Edition. Pearson Education Canada Inc.

[21] Scott, William, R. (1997), Financial Accounting Theory, International Edition, New Jersey: Prentice-Hall, Inc.

[22] Watts, R., \& Zimmerman, J. L. (1986). Positive Accounting Theory. Englewood Cliffs, $\mathrm{Nj}$ : Prentice Hall.

[23] Mc Nichols, M., F. (2000). Research Design Issues In Earnings Management Studies. Journal of Accounting And Public Policy, 19, 4-5, 313-345

[24] Cahan, S. F. (1992). The Effect Of Antitrust Investigation On Discretionary Accruals: A Refined Test Of Political Cost Hypothesis. The Accounting Review, 67(1), 77-95.

[25] Han, J. \& Wang, S. (1998). Political Costs And Earnings Management Of Oil Companies During The1990 Persian Gulf Crisis. The Accounting Review, 73 (1), 103-117.

[26] Key, K.G. (1997). Political Cost Incentives For Earnings Management In The Cable Television Industry. Journal Of Accounting And Economics, 23,.309337.

[27] Aryani, Dwi Septa. (2011). Manajemen Laba Pada Perusahaan Manufaktur Di Bursa Efek Indonesia. Jurnal Ekonomi Dan Informasi Akuntansi, 1 (2), 78-89

[28] Nurdiniah, Dade, Dan Linda Herlina. (2015). Analysis Of Factors Affecting The Motivation Of Earnings Management In Manufacturing Listed In Indonesia Stock Exchange. Research Journal Of Finance And Accounting, 6 (3) 100-106 
[29] Ali Belgasem-Hussain, H \& Hussaein, Y. I (2020). Earnings Management As An Ethical Issue In View Of Kohlberg's Theory Of Moral Reasoning. Journal of Financial Crime Emerald Publishing Limited 1359-0790. Http://Doi:10.1108/Jfc-11-2019-0138

[30] Priyastiwi, Sriwidharmanely \& Fatjriyati, K, F. (2020) Can The Ethical Orientation Mitigate The Manager's Earnings Management? Journal of Accounting And Investment, 21 (3), 417-433.

[31] Aditama, F \& Purwaningsih, A. (2014). Pengaruh perencanaan pajak terhadap manajemen laba pada perusahaan nonmanufaktur yang terdaftar di bursa efek Indonesia. Modus, 26 (1), 33-50, 2014

[32] Beneish, M. D. (2001). Earnings Management: A Perspective. Managerial Finance, $27 \quad$ (12), 317. https://doi.org/10.1108/030743501107 $\underline{67411}$

[33] Demski, J. S., \& Sappingtont, D. E. M. (1987). Delegated Expertise. Journal of Accounting Research, 25(1), 68-89.

[34] Anderson, I., and Louderback III, I. Autumn 1975. Income manipulation and purchase-pooling: Some additional results. Journal of Accounting Research 13(2), 338-343.

[35] Widyati, M., F. (2013). Pengaruh dewan direksi, komisaris independen, komite audit, kepemimpinan manajerial dan kepemilikan institusional terhadap kinerja keuangan. Jurnal Ilmu Manajemen, 1 (1), 234-249.

[36] Sianturia, J. A. TP, Wahyudi, S., Pangestuti, I. R. D., \& Utomo, M., N. (2020) Managerial opportunistic behavior and firm value: Empirical study of manufacturing companies in Indonesia. Management Science Letter. 2553-2560 http://dx.doi.org/10.5267/j.ms1.2020.3.040 